\title{
Editorial
}

\section{The maintenance of competence programme (MOCOMP)}

Every anaesthetist should consider the following questions:

How should anaesthetists' maintain their competence?

Are some forms of continuing medical education (CME) more effective than others?

Are some types and formats of CME more user friendly and acceptable than others?

The paper by Burrows and Fear ${ }^{1}$ in this issue provides important insights into these questions. Anaesthetists have strong views on what type of CME they like and what type of CME they want to attend. However, educators have questioned the effectiveness of many of the types of CME that anaesthetists utilise because the CME does not respond to specific, practice-related educational needs and is not focused on specific behavioural objectives. ${ }^{2,3}$

The Royal College of Physicians and Surgeons of Canada (RCPSC) and several of the speciality societies, including the Canadian Anaesthetists' Society, have developed the MOCOMP (Maintenance of Competence) Pilot Project. The philosophy of MOCOMP is to develop a comprehensive CME strategy which will motivate specialists to continuously update their clinical practice. The MOCOMP programme encourages participation, not by a system of punishments and rewards as run by the Royal Australian College of Obstetricians and Gynaecologists where mandatory CME is linked to licensure, but by motivating specialists to take responsibility for their own CME efforts.

The MOCOMP programme will achieve its objective by encouraging the specialist to apply the principles of total quality management to his/her CME efforts. The resources used, the outcome of the CME, in other words the effect on clinical practice, and the process whereby this outcome is achieved have to be considered. ${ }^{4}$

From the Departments of Anaesthesia, Victoria General Hospital and Dalhousie University, Halifax, Nova Scotia, B3H 2 Y9 and the McKellar General Hospital, Thunder Bay, Ontario, P7E 1 G6

Accepted for publication 29th March, 1993.
The design of the MOCOMP programme has been modified as the pilot project progressed from its inception in 1991. The programme now has three components: (1) a credit system to promote production of high quality, practice based, educational programmes, (2) a selfdirected CME plan designed to motivate individual specialists to record and critically appraise their CME activities, and (3) an annual, personalised CME profile.

Information from the MOCOMP Pilot Project (November 1992) demonstrates that anaesthetists who have enrolled in the pilot project and have submitted evidence of their CME activities spend half of their recorded time engaged in scholarly activities, i.e., teaching, writing papers, and research. Provider-sponsored activities such as the Annual Meeting, Provincial Divisional Meetings and other organised meetings accounted for a third of the recorded time; less than a sixth of the time was spent on self-directed CME activities, i.e., in depth review of a topic, self-assessment programme, computer learning programme, traineeship. The direct effect on patient care of activities such as teaching and research can be questioned.

These findings led the MOCOMP coordinators to redefine the process of a self-directed CME curriculum so as to allow MOCOMP members to use CME resources to achieve outcomes that impact on their clinical practice and thus have a potential effect on their competence. ${ }^{4}$

There are many ways that physicians obtain information on a regular basis, i.e, reading, teaching, consultations, rounds, research, etc. Many of these activities are too numerous to record on a regular basis and rarely lead to a change in practice. This information screening is defined as Level I activity - "General Professional Activity" - in the revised MOCOMP Programme. It consists of scanning one's professional environment for new ideas. Some information does capture the interest of the specialist who might then explore the area in more detail; this is called Level II activity - "In Depth Review" these activities are goal-orientated, more focused and should lead to an outcome after completion. The following outcomes are possible: 
1 I will modify my practice; or

2 I will wait for further information before I modify my practice; or

3 I see no need to modify my practice.

The recording of self-directed CME in the MOCOMP Diary has been restricted to Level II CME activities; activities which address specific topics in depth and allow the specialist to express the potential impact on his/her practice.

Burrows and Fear's article demonstrates that the attitude of anaesthetists, both community-based and university-affiliated, to the CME activities needs to change. ${ }^{1}$ There is the perception by many respondents of their survey that journal reading, listening to audio cassettes, viewing video tapes and attending passive $\mathrm{CME}$, such as lectures or other non-interactive formats, are effective CME tools; but this is not supported by many educators. ${ }^{2}$ Interestingly, hospital and/or departmental rounds were viewed as poor educational experiences which should suggest a major need to review these activities at a local level so as to incorporate the principles of adult learning into this $\mathrm{CME}$ format.

It is encouraging that many anaesthetists recognise that they have no formal assessment of their educational needs and that an overwhelming majority would consider participating in a formalised needs assessment programme. Davis et al. have noted that CME is more effective when it incorporates practice-based enabling and reinforcing strategies with adequate assessment of physicians' needs. ${ }^{5}$ The Canadian Anaesthetists' Society should consider taking a leading role in the development of needs assessment programmes for anaesthetists in Canada.

There is a need for the anaesthesia community to develop new approaches to, and methods of, educational activities for anaesthetists; the use of more interactive formats at meetings should be encouraged. The design and availability of self-assessment programmes and quizzes, computer-based learning programmes and other selfdirected methods of CME have to be enhanced. Barriers to CME, specifically, the time available, cost, lack of availability of locum tenens, quality of programmes, etc. need to be addressed by all players - physicians, educators, hospitals, universities and government.

MOCOMP will help anaesthetists to develop a comprehensive personal CME strategy, motivate the continuous updating of clinical practice and stimulate the development of more innovative and educationally effective CME activities.

\section{Le programme du maintien de la compétence}

Tout anesthésiste doit un jour s'interroger sur la façon de maintenir sa compétence.

Est-ce que certaines formules d'enseignement médical continu (EMC) sont plus efficaces que d'autres?

Certain types ou formats sont-ils plus accessibles et plus profitables?

L'article de Fear et Burrows ${ }^{1}$ publié ce mois-ci fournit un excellent sujet de réflection sur ces questions. Les anesthésistes ont des opinions bien tranchées sur le type qu'ils préfèrent et pour lequel ils sont prêts à se déplacer. Cependant, les éducateurs se posent des questions sur l'efficacité de plusieurs de ces activités d'EMC parce qu'elles ne correspondent pas à des besoins de formation reliés à l'exercice de l'anesthésie et qu'elles ne proposent pas des objectifs comportementaux spécifiques. ${ }^{2-3}$

Le Collège Royal des Médecins et Chirurgiens du Canada et plusieurs autres associations de spécialistes ont mis au point le projet-pilote MOCOMP (pour maintien de la compétence). La philosophie du MOCOMP est de développer une stratégie d'EMC qui a pour effet de motiver le spécialiste à mettre à jour sa pratique clinique de façon continue. Le programme MOCOMP encourage la participation, non pas de façon coercitive par l'attribution de punitions et récompenses comme le fait le Collège Royal Australien des Obstétriciens et Gynécologues où le permis d'exercice est lié à l'EMC, mais en motivant les spécialistes à prendre la responsabilité de leur propre réussite en EMC.

Le programme MOCOMP atteindra ces objectifs en encourageant le spécialiste à appliquer les principes de la qualité totale dans ses activités pédagogiques permanentes. Les ressources utilisées, les résultats de l'EMC, en d'autres mots leur influence sur l'exercice professionnel et le processus par lequel ces résultats sont obtenus, doivent être étudiés. ${ }^{4}$

La conception du programme MOCOMP a té modifiée à mesure que le projet pilote progressait depuis sa mise en marche en 1991. Le programme contient maintenant trois parties: 1) un système de crédits pour promouvoir la production de programmes éducatifs cliniques de haute qualité, 2) un plan d'EMC auto-contrôlé conçu pour motiver le spécialiste à enregistrer et évaluer ses activités d'EMC et 3 ) un profil d'EMC annuel et personnalisé. 
Les renseignements obtenus sur le projet-pilote $\mathrm{MO}$ COMPS (novembre 1992) démontre que les anesthésistes qui ont participé au projet et ont soumis un bilan de leur activités édicatives, passaient la moitié de leur temps en milieu académique en enseignant, en écrivant des articles ou en formant des élèves. Les effets directs d'activités telles que l'enseignement et la recherche sur les soins sont douteux.

Ces données ont amené une redéfinition par les coordinateurs du MOCOMP du processus d'auto-gestion du curriculum d'EMC de façon à permettre aux membres participants d'utiliser les ressources d'EMC aptes à produire un impact sur la pratique clinique et ainsi un effet sur la compétence. ${ }^{4}$

Pour se maintenir à jour, le médecin dispose de plusieurs moyens comme le lecture, les cours, les consultations, les tournées, la recherche, etc. Plusieurs de ces activités sont trop fréquentes pour qu'on les enregistre et ne produisent que rarement un changement de pratique. Cette information est décrite comme le premier niveau d'activité - "Activité générale professionnelle" dans le programme MOCOMP révisé. Il consiste à scruter son milieu professionnel à la recherche de nouvelles idées. Certaines informations peuvent aiguiser la curiosité de l'anesthésiste qui peut alors pousser son exploration pour obtenir plus de détails; ceci s'appelle une activité de second niveau ou "révision en profondeur ". Ces activités sont orientées vers un objectif, plus spécifique et une fois terminées, produisent des résultats tangibles. Ces résultats sont exprimés d'une des façons suivantes:

1 je vais modifier ma pratique; ou

2 je vais attendre d'autres informations avant de la modifier; ou

3 je ne sens pas le besoin de la modifier.

L'enregistrement dans l'agenda MOCOMP de l'EMC auto-dirigé est limité aux activités de deuxième niveau, soit à des activités qui abordent en profondeur des sujets spécifiques et permettent au spécialiste d'en juger l'impact sur sa pratique.

L'article de Burrows et Fear illustre que l'attitude de l'anesthésiste, qu'il vienne du milieu communautaire ou universitaire, doit modifier ses activitiés d'EMC. ${ }^{1}$ Plusieurs des répondants au questionnaire perçoivent la lecture d'articles, l'écoute de cassettes audio et l'assistance passive à l'EMC, comme à des conférences ou à d'autres activités non interactives, comme des outils d'EMC efficaces mais ceci n'est pas confirmé par les éducateurs. ${ }^{2}$ Il est intéressant de noter que les tournées hospitalières ou départementales sont considérés comme des expériences pédagogiques de peu de valeur, ce qui laisse croire qu'une révision locale de ces activités est nécessaire. Cette révision doit incorporer les principes de l'andragogie.
Il est encourageant de savoir que beaucoup d'anesthésistes reconnaissent qu'ils ne possèdent pas d'évaluation de leur besoin pédagogiques et qu'une très forte majorité pourrait participer à un programme formel d'valuation de ces besoins. ${ }^{5}$ La Société canadienne des anesthésistes devrait penser à jouer un rôle de leader dans le mise au point d'un programme d'évaluation des besoins pour les anesthésistes du Canada.

L'ensemble des anesthésistes a besoin de nouvelles approches et méthodes éducatives; on doit encourager l'utilisation de formules interactives lors des réunions scientifiques. On doit favoriser la mise au point et la disponibilité de programme d'auto-évaluation, de questionnaires, de programmes éducatifs informatisés et d'autres méthodes autocontrôlées. Les obstacles à $\mathrm{IEMC}$, et spécifiquement, les facteurs temps et coûts, le manque de remplaçants, la qualité des programmes etc., sont l'affaire de tous, médecins, éducateurs, hôpitaux, universités et gouvernements.

Le MOCOMP permettra aux anesthésistes de développer une stratégie personnelle pour ses besoins d'EMC, de le motiver pour une mise à jour continuelle et de stimuler la mise au point d'activités pédagogiques plus innovatives et plus efficaces de formation continue.

\section{References}

1 Burrows FA, Fear DW. Maintenance of competence: a comparative study of continuing medical education practices of community-based and university-affiliated anaesthetists in Ontario. Can J Anaesth 1993; 40: ?? - ??

2 Wentz $D K$. Continuous medical education at a crossroads. JAMA 1990; 264: 2425-6.

3 Manning PR, Petit DW. The past, present, and future of continuing medical education. Achievements and opportunities, computers and recertification. JAMA 1987; 258: 3542-6.

4 Parboosingh IJT, Gondocz ST. The maintenance of competence (MOCOMP) program: motivating specialists to appraise the quality of their continuing medical education activities. Can J Surg 1993; 36: 29-32.

5 Davis DA, Thomson MA, Oxman AD, Haynes RB. Evidence for the effectiveness of CME. A review of 50 randomized controlled trails. JAMA 1992; 268: 1111-7. 